\title{
B-Chromosomes in Gymnosperms
}

\author{
S. Rastogi and D. Ohri
}

Research Cell, Amity University Uttar Pradesh, Licknow Campus, Malhaur, P.O. Chinhat, Luc know-226028 (U.P.)

Corresponding author: Deepak Ohri, Email: dohri@lko.amity.edu, ohri_deepak@rediffmail.com

\begin{abstract}
B-chromosomes show a non-random distribution in different taxa of gymnosperms. They are generally smaller and show similar centromeric position as the normal complement and are heterochromatic in nature and may show DAPI or CMA banding. They are generally devoid of any gene content, do not pair at meiosis and show accumulation through female line. They show incremental effect on genome size and some adaptive value in particular ecological conditions.
\end{abstract}

Keywords: : B-chromosomes, gymnosperms, frequency, meiotic pairing, adaptive value

\section{Introduction}

Supernumerary or B-chromosomes are dispensable components of genome as they can be absent in certain individuals of a population, they show lack of pairing with $\mathrm{A}$ chromosomes because of genetic differentiation, and non-mendelian inheritance due to meiotic drive (Jones \&Houben 2003). The origin of Bs is still an enigma nevertheless, they are generally considered to arise from A chromosomes (Jones et al. 2008). A convincing case in this respect is that of Plantago lagopus in which a trisomic for chromosome 2 after undergoing structural changes and massive accumulation of 5SrDNA sequences acquires B chromosome like properties (Dhar et al. 2002). They have wide distribution, being known from about 1300 plant species (Camacho 2005). However, their distribution is non-random among various taxonomic groups (Jones et al. 2008). Their adaptive value is not well established but it is observed that they are more common in plants inhabiting suboptimal and extreme conditions (Kunakh 2010). It is generally considered that B's are more frequent in species with larger genomes than those with smaller genomes, however they show negative correlation with ploidy levels (Trivers et al. 2004). Nevertheless, these correlations are not commensurate with the occurrence of Bs in nearly 40 species of hardwoods which both have smaller genomes as well as chromosome sizes (see Jones 1995, Ohri 2015). Gymnosperms, which have much larger genomes show the incidence of B-chromosomes in 31 out of a total of 633 species known cytologicaly, making up $5 \%$ of the total (unpublished data). An account of B-chromosomes in gymnosperms has been given by Muratova (2018). The present account however, systematically deals with not only the presence but various other aspects including their structure, frequency and biological significance of B-chromosomes in this important group of seed plants having great forestry importance.

\section{Distribution}

The distribution of B-chromosomes is non-random (Table 1) as these are completely absent in subclass Cycadidae. Family Ephedraceae has a single case of Ephedra major showing 1-2 B chromosome. In Pinaceae there is a single report in Pinus sylvestris and two in Larix. However, 19 Picea species with Bs have been reported till now. In Podocarpaceae the single report of Podocarpus macrophyllus shows a maximum number of 7 Bs 
Table 1

B chromosmes in gymnosperms

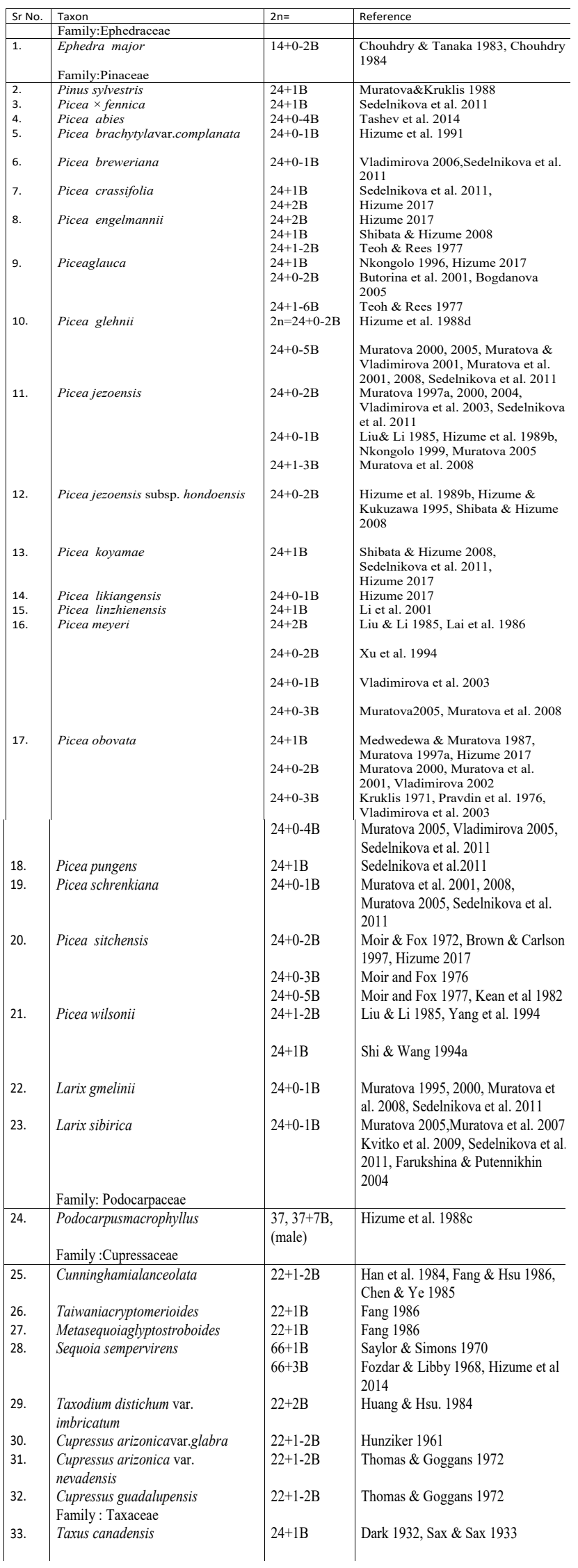

reported in gymnosperms. In Cupressaceae Bs have been studied in monotypic genera e.g. Cunninghamia, Taiwania, Metasequoia, Sequoia, and in one and three species of Taxodium and Cupressus respectively. Family Taxaceae also has a single report of Taxus canadensis (Table 1).

\section{Size and Structure}

B-chromosomes as observed in various species are much smaller than the smallest chromosome of A complement and generally metacentric or sub-metacentric in all the species studied (Table 1). The frequency of occurrence of these two types of Bs has been noted in Picea sitchensis where meta- and submetacentric Bs are 82.4 and 17.6 per cent respectively (Moir \& Fox 1977). This is in accordance with earlier studies which show a similarity of morphology between $\mathrm{A}$ and $\mathrm{B}$ chromosomes of a species (Camacho 2005).

B-chromosomes in Picea glauca are facultatively heterochromatic because when present they form distinct chromocentres which even makes it possible to determine their number, however the constitutive heterochromatin is not indicated by Giemsa staining (Teoh \& Rees 1977). In Sequoia sempervirens however, the B chromosome is euchromatic (Saylor \& Simons 1970). Fluorescent banding has been studied in some Picea species and Sequoia sempervirens. While both CMA and DAPI bands are seen in Picea glauca other species show either DAPI or CMA bands (Table 2).

Table 2

Fluorescent staining of B chromosomes

\begin{tabular}{|l|l|c|c|l|}
\hline Sr & \multirow{2}{*}{ Species } & Fluorescent banding & Reference \\
\cline { 3 - 4 } No & & CMA & DAPI & \\
\hline 1. & Picea crassifolia & - & - & Hizume 2017 \\
\hline 2. & Picea glauca & + & - & Hizume 2017 \\
\hline 3. & Picea koyamae & - & + & Hizume 2017 \\
\hline 4. & Picea likiangensis & - & + & Hizume 2017 \\
\hline 5. & Picea obovata & - & + & Hizume 2017 \\
\hline 6. & Picea sitchensis & + & - & Hizume 2017 \\
\hline 7. & Picea glehnii & - & + & Hizume 1988d \\
\hline 8. & Pice ajezoensis & - & - & Hizume et al. 1989b \\
\hline 9. & $\begin{array}{l}\text { Picea jezoensis subsp. } \\
\text { hondoensis }\end{array}$ & - & - & $\begin{array}{l}\text { Hizume et al. 1989b, } \\
\text { Hizume \& Kukuzawa 1995 }\end{array}$ \\
\hline 10. & Sequoia sempervirens & + & - & Hizume et al.2014 \\
\hline
\end{tabular}

\section{Frequency}

As is evident from Table 3 Bs occur in a very small frequency in Larix species where L. sibirica and L. gmelinii show an incidence of 1.6 and 6.7 per cent respectively in the seedlings studied (Sedelinkova et al. 2011). However, in Picea species this frequency may be as high as $45.5 \%$ in a population (Hizume et al. 1991), but there is negative correlation between the number of Bs in an individual and their frequency of occurrence in the population (Table 3). 
Table 3

Per cent frequency of number of B's in different species

\begin{tabular}{|l|l|l|l|l|}
\hline $\begin{array}{l}\text { Sr } \\
\text { No. }\end{array}$ & Species & No. of B's & $\begin{array}{l}\text { Occurrence } \\
(\%)\end{array}$ & Reference \\
\hline 1. & Larix sibirica & 1B & 1.6 & Sedelinkova et al 2011 \\
\hline 2 & Larix gmelinii & 1B & 6.7 & Sedelinkova et al 2011 \\
\hline 3. & Picea obovata & 1B & 11.0 & Pravdin et al. 1976 \\
\hline & & 2B & 6.0 & Pravdin et al. 1976 \\
\hline & & 1B & $20.8-25.9$ & Kruklis 1971 \\
\hline & & 2B & $2.0-3.8$ & Kruklis 1971 \\
\hline & & 3B & 1.8 & Kruklis 1971 \\
\hline 4. & Picea glehnii & 1B & 19.5 & Hizume et al. 1988d \\
\hline & & 2B & 1.9 & \\
\hline 5. & $\begin{array}{l}\text { Picea brachytyla } \\
\text { var. complanata }\end{array}$ & 1B & 45.5 & Hizume et al 1991 \\
\hline
\end{tabular}

\section{Gene content}

Many B chromosomes have been known to include rDNA genes (Jones 1995, Camacho 2005). In Picea obovata silver nitrate staining shows clear telomeric blocks indicating presence of active nucleolar organizers (Sedelinkova et al. 2011). However, in Picea engelmanii, P. jezoensis var. hondoensis and $P$. koyamae the FISH signals of neither $45 \mathrm{~S}$ nor $5 \mathrm{~S}$ rDNA have been observed (Hizume \& Kukuzawa 1995, Shibata \& Hizume 2008).

\section{Meiotic pairing and transmission}

Studies in Picea sitchensis show that Bs neither pair with each other nor with A chromosomes and at metaphase I and they are randomly distributed around equatorial plate (Kean et al. 1982). Controlled crosses performed in this species show that the transmission of Bs through the male parent does not show any significant gain or loss while there is marked accumulation through female line possibly by preferential segregation towards the pole producing single functional megaspore after second division (Kean et al 1982, Fox 1987).

\section{Nucleotypic effects and adaptability}

Since $B$ s are present in addition to the normal complement it is natural that they effect the genome size of an organism. Detailed studies in this respect have been made in Picea glauca (Teoh \& Rees 1976, 1977). While no significant differences were found in 2C DNA amounts in 26 provenances without Bs (Teoh \& Rees 1976) an incremental addition of $2.7 \%$ of the total genomic DNA of A complementper B chromosome, was observed ultimately making up $16 \%$ of the genome size for the maximum of 6 Bs found in this species (Teoh \& Rees 1977). Such increase in DNA amounts has been seen in many other cases as in maize it can be as high as 155 per cent (Rees 1974).

Some studies have been made on the effect of Bs on growth parameters and clinal variation in their frequency in different environments. In Picea glauca the Bs were found in 48 of the 51 populations studied and in 90 per cent of the plants. The study area was divided east to west by $95^{\text {th }}$ meridian and it was found that the $B$ frequency per plant in eastern maritime region was 2.25 times more than in western region and this variation coincided with rainfall pattern which was high in eastern provinces (130-150 cm per year) as compared to the northwest territories ( $25 \mathrm{~cm}$ per year). This shows that B frequency increases with increasing rainfall (Teoh \& Rees 1977). This was corroborated further by providing artificial competition among young plants by growing them in conditions of different densities which confirmed differential mortality of plants with or without Bs under stress (Teoh\& Rees 1977). Similar observations were made in Allium schoenoprasum where the seeds carrying Bs show germination advantage under drought conditions as compared to the ones without Bs (Holmes \& Bougourd 1991). However, Moir and Fox (1976) found no major effect on growth rate related to Bs in Picea sitchensis. Such aspects concerning Bs in conifers might have strong implications in forestry and should be dealt with in detail.

\section{Acknowledgements}

We are grateful to DBT, Govt. of India, New Delhi for financial assistance. Thanks are also due to Pro-ViceChancellor and Dean Science and Technology Amity University Uttar Pradesh, Lucknow Campus for encouragement and support.

\section{References}

Bogdanova EV (2005) Cytogenetic characteristics of the homeostasis of Piceaglauca( =P. canadensis) in the conditions of introduction and anthropogenic stress. Pages 13--15 in Karyology, Karyosystematics and Molecular Phylogeny. St. Petersburg, Russia

Brown GR, Carlson JE (1997) Molecular cytogenetics of the genes encoding 18s-5.8s-26s rRNA and 5s rRNAin two species of spruce (Picea) Theoretical and Applied Genetics 95: 1-9. https://doi.org/10.1007/s001220050526

Butorina AK, Bogdanova EV (2001) Adaptive significance and possible origin of B-chromosomes in Piceaglauca (Moench,) Voss = P. canadensis B. S. P. Citologija 43(8): 809-814

Camacho JPM (2005) B chromosomes In: The Evolution of Genome, Gregory TR (ed.), Elsevier Inc.pp. 223-286. https://doi.org/10.1016/b978-012301463-4/50006-1

Chouhdry AS (1984) Karyomorphological and cytological studies in Ephedra. J. Sci. Hiroshima Univ., Ser. B,. 19: 57-109

Chouhdry SA, Tanaka R (1983) On the occurrence of accessory chromosomes in Ephedra major. Chromosome Inf. Serv. 35: 26-27

Farukshina GG, Putenikhin VP (2004) Karyotype analysis of Larix sukaczewii in the Urals. Lesovedenije. 6: 25-33. (in Russian with Englishsummary)

Dhar MK, Friebe B, Kaul AK, Gill BS (2002) Origin of an apparent B chromosome by mutation, chromosome fragmentation and specific DNA sequence amplification. Chromosoma 111: 332-340.

https://doi.org/10.1007/s00412-002-0214-4

Fox DP (1987) The chromosomes of Piceasitchensis (Bong.) Carr. And its relatives. Proceedings of the Royal Society of Edinburgh, Sect. BBiological Science 93: 51-59. https://doi.org/10.1017/s0269727000006278

Hizume M (2017) Chromosome banding in Picea IV. Comparative karyotype analysis of fluorescent band patters of 25 taxa. Chromosome Botany 12: 1732. https://doi.org/10.3199/iscb. 12.17

Hizume M, Kuzukawa Y (1995) Fluorescent chromosome banding in Picea II.Relationships between rDNA loci and chromomycin A3-bands in somatic chromosomes of P. jezoensis var. hondoensis.Kromosomo 79-80: 27542759

Hizume M, Kishimoto K, Tominaga K, Tanaka A (1988d) Presence of B-chromosome in Picea glehnii (Pinaceae). Kromosomo 51-52: 1715-1720

Hizume M, Kishimoto K, Kubo Y, Tanaka A (1989b) Fluorescent chromosome banding in Picea I. Difference in chromomycin A3 band pattern between $\mathrm{P}$. 
jezoensis var. jezoensis and P. jezoensis var. hondoensis. Kromosomo 53: $1736-1744$

Hizume M, Kondo K, Zhang S, Hong D (1998c) Fluorescence chromosome banding in Chinese larch LarixchinensisBiessn. Chromosome Science 2: 95-98

Hizume M, Kitazawa N, Gu Z, Kondo K (1991) Variation of fluorescent chromosome band in Picea brachytyla var. complanata collected in Yunnan, China. Kromosomo 63-64: 2149-2158

Jones RN (1995) B chromosomes in plants. New Phytologist 131: 411-434. https://doi.org/10.1111/j.1469-8137.1995.tb03079.x

Jones RN, Viegas W, Houben A (2008) A century of B chromosomes in plants: so what? Annals of Botany 101: 767-775. https://doi.org/10.1093/aob/mcm167

Jones N, Houben A (2003) B chromosomes in plants: escapees from the A chromosome genome? Trends in Plant Science 8: 417-423. https://doi.org/10.1016/s1360-1385(03)00187-0

Kean VM, Fox DP, Faulkner R (1982) The accumulation mechanism of the supernumerary (B-) chromosome in Picea sitchensis (Bong.) Carr. And the effect of this chromosome on male and female flowering.Silvae genetic 31: 126131

Kruklis MV (1971) Additional chromosomes in gymnosperm Picea obovata. Dokl.Akad.Nauk SSSR 196: 1213

Kunakh VA (2010) Additional or B chromosomes of plants. Origin and biological significance. Bulletin of the Society of Geneticists and Breeders 8: 99-139

Kvitko OV, Muratova EN, Syzikh OA, Viladimorova OS (2009) Chromosome numbers of some conifer species. Botanicheskii Zhurnal 94: 305-307 (in Russian)

Li LC, Wang G, Su S (2001) Karyotype analysis of four species in Picea (Pinaceae). Guihaia 21(1): 43-46

Liu YH, Li MX (1985) Karyotype analysis of five species of genus Picea. J. Wuhan Bot. Res. 3(3): 203-207

Medwedewa NS, Muratova EN (1987) Karyological investigation of the Siberian spruce (Picea obovata Ledeb.) from Yakutian ASSR.Izv.Sibirsk.Otd.Akad. Nauk SSSR, Ser. Biol. Nauk 1: 15-21

Moir RB, Fox DP (1972) Supernumerary chromosomes in Picea sitchensis (Bong.) Carr. SilvaeGenetica 21: 182-186

Moir RB, Fox DP (1976) Supernumerary chromosomes and growth rate in Picea sitchensis (Bong.) Carr. SilvaeGenetica 25: 139-141

Moir RB, Fox DP (1977) Supernumerary chromosome distribution in provenances of Picea sitchensis (Bong.) Carr. SilvaeGenetica 26: 26-33

Muratova NE (1997a) Studies on nucleolar chromosomes in representatives of PinaceaeLindl. In: Cytogenetic studies of forest trees and shrub species ed. Borzan Z \& Schlarbaum SE, Proceedings of the first IUFRO cytogenetics Working Party S2.04-08 Symposium Sept. 8-11 1993 pp 45-72

Muratova EN (2000) Karyotipic variability and anomalies in populations of conifers from Siberia and the Far East. Pages 129-141 in H. Guttenberger, Ž. Borzan, S. E. Schlarbaum \& T. P. V. Hartman (eds), Cytogenetic Studies of Forest Trees and Shrubs-Review, Present Status, and Outlook on the Future. Arbora Publishers, Zloven, Slovakia

Muratova EN (2005) Caryological and cytogenetic studies of coniferous plants of Siberia and Far East.Sibirskiï̈kol.Žur. 12(5): 573-582

Muratova EN (2018) B chromosomes in gymnosperms-a review. The International Journal of Plant Reproductive Biology 10: 14-25

Muratova EN, Vladimirova OS (2001) B-chromosomes in Picea glehnii (Pinaceae) Bot. Žhurn.(Moscow \& Leningrad) 86(5): 125-130

Muratova EN, Sedelnikova ST, Pimenov AV, Karpjuk TV , Sizikh OA, Kvitko OV (2007) Karyological analysis of larch species from Siberia and far east of Russia. Forest Science Technol 3: 89-94. https://doi.org/10.1080/21580103.2007.9656323

Muratova EN, Sedelnikova TS, Karpyuk TV, Vladimirova OS, Pimenov AV, Mikheeva NA, Bazhina EV, Kvitko OV (2008) Karyological and cytogenetic studies of conifers from West Siberia and far East. Contemporary Problems in Ecology 1: 263-271. https://doi.org/10.1134/s1995425508020148

Muratova EN, Kruklis MV (1988) Chromosome numbers of gymnospermous plants. Nobosiberisk Science, Siberian Branch, pp120

Muratova EN, Vladimirova OS (2001) B-chromosomes in Picea glehnii (Pinaceae). Bot. Žhurn.(Moscow \& Leningrad) 86(5): 125-130

Nkongolo KK (1996) Chromosome analysis and DNA homology in three Piceaspecies, P. mariana, P. rubens, and P. glauca. Plant Systematics and Evolution 203: 27-40. https://doi.org/10.1007/bf00985235
Ohri D (2015) How small and constrained is the genome size of angiosperm woody species. Silvae Genetica 64: 20-32. https://doi.org/10.1515/sg-2015-0002

Pravdin LF, Abaturova GA, Shershakova OP (1976) Kryological analysis of European and Siberian spruce and their hybrids in the USSR. SilvaeGenetica 25 $89-95$

Rees H (1974) B chromosomes. Science Progress, Oxford 61: 535-554.

Saylor LC, Simons HA (1970) Karyology of Sequoia sempervirens: karyotype and accessory chromosomes. Cytologia 35: 294-303. https://doi.org/10.1508/cytologia.35.294

Sedelnikova TS, Muratova EN, Pimenov AV (2011) Variability of chromosome numbers in gymnosperms. Biology Bulletin Reviews 1: 100-109. https://doi.org/10.1134/s2079086411020083

Shibata F, Hizume M (2008) Comparative FISH karyotype analysis of 11 Piceaspe cies. Cytologia 73: 203-211. https://doi.org/10.1508/cytologia.73.203

Shi DX, Wang ML (1994a) Karyomorphological studies of 6 species in genus Picea. Acta Bot. Yunnan. 16(2): 157-164

Tashev AN, Sedelnikova TS, Pimenov AV (2014) Supernumerary B chromosomes in populations of Picea abies (L.) H. Karst. From western Rhodopes (Bulgaria). Tsitol.Genet. 48: 30-36. https://doi.org/10.3103/s0095452714030116

Teoh SB, Rees H (1976) Nuclear DNA amounts in populations of Picea and Pinus species. Heredity 36: 123-137. https://doi.org/10.1038/hdy.1976.12

Teoh SB, Rees H (1977) B chromosomes in white spruce. Proceedings Royal Society of London B 198 : 325-344. https://doi.org/10.1098/rspb.1977.0101

Trivers R, Burt A, Pelestis B (2004) B chromosomes and genome size in flowering plants. Genome 47: 1-8. https://doi.org/10.1139/g03-088

Vladimirova OS (2002) Karyological features of the Siberian spruce (Picea obovataLedeb.) from different provenances. Citologija 44(7): 712-718

Vladimirova OS (2005) Karyological features of Siberian spruce (Picea obovataLedeb.) under antropogenic contamination conditions of Krasnoyarsk. Ecol. Genet. 3(1): 18-23. https://doi.org/10.17816/ecogen3118-23

Vladimirova OS (2006) B-Chromosomes in karyotype of PiceabrewerianaWats. Pages 22--23 in Proceedings of the I (IX) Conference of Young Botanists in Saint Petersburg, May 21--26, 2006. Saint Petersburg

Vladimirova OS, Karpyuk TV, Muratova EN (2003) Chromosome numbers of some Picea species (Pinaceae). Bot. Žhurn. (Moscow \& Leningrad) 88(8): 112-113

Xu WD, Li WD, Zhang Y (1994) A study on taxonomy of Picea mongolica in Inner Mongolia. Bull. Bot. Res., Harbin 14(1): 59-68

Yang ZY, Gong X (2013) Karyotype analysis of five species of Cycas(Cycadaceae) in China. Plant Diversity and Resources 35: 601-604 